\title{
lodine deficiency and its association with intelligence quotient in schoolchildren from Colima, Mexico
}

\author{
Alicia Pineda-Lucatero', Laura Avila-liménez ${ }^{2}$, Rosa Isela Ramos-Hernández ${ }^{3}$, \\ Clementina Magos ${ }^{4}$ and Homero Martínez ${ }^{5,6, *}$ \\ 'Unidad de Investigación en Epidemiología Clínica, IMSS-Colima, Colima, México: ${ }^{2}$ Coordinación Clínica de \\ Educación e Investigación en Salud de HGR MF No. 1, IMSS-Cuernavaca, Morelos, México: ${ }^{3}$ Unidad de \\ Investigación en Epidemiología Nutricional, IMSS-México DF, México: ${ }^{4}$ Instituto Nacional de Diagnóstico y \\ Referencia Epidemiológica, Secretaría de Salud, México DF, México: ${ }^{5}$ Hospital Infantil de México 'Federico \\ Gómez', Subdirección de Investigación Médica, México: 'RAND, 1776 Main Avenue, PO Box 2138, Santa \\ Monica, CA 90407-2138, USA
}

Submitted 29 January 2007: Accepted 9 September 2007: First published online 21 January 2008

\begin{abstract}
Objective: To determine the prevalence of iodine deficiency, its causes and its association with intelligence quotient (IQ) in Mexican schoolchildren.

Design: Cross-sectional analytical study, in which determinations of thyroid gland size, urinary iodine excretion, IQ, iron nutritional status, physical anthropometry, family consumption of goitrogenic foods, type/origin and iodine saturation of salt consumed at home and coliform organisms in drinking water were performed, and the association of each variable with IQ scores was evaluated by multiple regression analyses.

Setting: Municipality of Cuauhtémoc, in Colima, Mexico (altitude: 600-2700 m above sea level). Sea salt is extracted manually nearby and often used for human consumption. Goitre remains present in the region despite over half a century of mandatory salt iodination in the country.

Subjects: Three hundred and three children, similar proportions of boys and girls, mean age 9.3 years, randomly selected from 19 public elementary schools.

Results: Overall goitre rate was $21.4 \%$; low urinary iodine excretion was found in $19.5 \%$ of the children, high urinary iodine excretion in $32.0 \%$. IQ scores were transformed into percentile values, with the following categorisation: $\leq \mathrm{P} 5$ (low IQ), $48.5 \%$; $>$ P5 to $\leq$ P25 (below average), $24.2 \%$; $>$ P25 to $<$ P75 (average), $18.8 \%$; $\geq \mathrm{P} 75$ to $<\mathrm{P} 95$ (above average), 3.6\%; $\geq \mathrm{P} 95$ (high IQ), 4.9\%. Ninety-two per cent of the population used iodinated salt, but deficient iodine saturation $(<50 \mathrm{ppm})$ was found in $86.8 \%$ of salt samples. The main goitrogenic foods consumed were peanuts (by $31.5 \%$ of the sample), cabbage $(30 \cdot 1 \%)$, broccoli $(27.7 \%)$ and cauliflower (25.7\%). Median counts of coliform organisms (colony-forming units $/ 100 \mathrm{ml}$ of drinking water) were: 207.5 (well water), 151 (cisterns), 52 (private homes), 25 (elementary schools) and 12 (kindergartens). Moderate iodine deficiency was associated $(P<0.05)$ with a 4.26 times higher risk of low IQ. Conclusions: There is a perturbing negative impact of these findings on human capital acquisition for the region and the country. More attention is needed to ensure effective salt iodination processes, particularly in regions where goitrogens may contribute to the negative effects of iodine deficiency on the intellectual development of children.
\end{abstract}

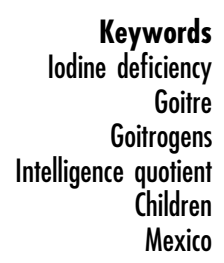

Iodine is part of the thyroid hormones triiodothyronine and thyroxine, necessary for central nervous system development ${ }^{(1,2)}$. The most obvious consequence of iodine deficiency is goitre, an excessive growth of the thyroid gland ${ }^{(3)}$. The prevalence of goitre in children is an important indicator of iodine deficiency disorders (IDD) in a population: $\mathrm{a} \geq 5 \%$ prevalence of goitre is considered a public health problem ${ }^{(4)}$. IDD include a wide range of alterations $^{(5)}$; because adequate quantities of thyroid hormone are crucial in foetal brain development, limited neuro-intellectual development is among the greatest concerns $^{(1,6,7)}$. Neurological damage and childhood mental retardation caused by iodine deficiency in early life are irreversible ${ }^{(8-10)}$. In areas with iodine deficiency, 
newborns are at high risk for neurological disorders and mental retardation from the combined effects of iodine deficiency in the mother and neonatal hypothyroxinaemia in the foetus ${ }^{(11,12)}$. Several studies carried out in areas with moderate iodine deficiency have also shown the presence of motor and intellectual development abnormalities in children and in adults. Although different methods have been used to assess intellectual development, the findings include low visual-motor execution, decreased motor skills, limitations in perceptual and neuromotor abilities, and low intelligence quotient $(\mathrm{IQ})^{(13,14)}$. Recent reports in the literature showed a moderate improvement in the processing of information, fine motor abilities and resolution of visual problems in school-aged children who were moderately iodinedeficient, after iodine repletion ${ }^{(15-17)}$.

Iodine deficiency is more common in mountainous areas. When it rains, the iodine in mountain soil is washed away into areas of lower altitude, because of its high solubility in water ${ }^{(8,18)}$. However, iodine deficiency can appear at any altitude. In its 2002 assessment of the world nutrition situation, the United Nations Administrative Committee on Coordination/Sub-Committee on Nutrition estimated that about 740 million people were affected by goitre, and more than 2 billion were at risk of IDD ${ }^{(19)}$. In 2005, the World Health Organization (WHO) estimated that 285 million school-aged children $(36.5 \%$ of the world subpopulation) ingested insufficient amounts of iodine $^{(20)}$. In its most recent update of the child population affected by IDD, the United Nations Children's Fund (UNICEF) estimated that $18 \%$ of the world's 6-11-yearolds, and $11 \%$ of that same age range in Latin American and the Caribbean, suffered from goitre ${ }^{(21)}$.

Salt iodination has been regarded as one of the most effective interventions to control endemic goitre ${ }^{(22)}$. In Mexico, salt iodination has been regulated by the Ministry of Health since 1960. The effectiveness in decreasing the prevalence of goitre in the country has led to laxness in epidemiological alertness concerning IDD. One of the latest reports by national health authorities states that the rate of endemic goitre for 2000-2004 in Mexico was under 2 per 100000 inhabitants, attributing this to the extensive salt iodination carried out in the country. However, some states have less encouraging results. At the time of the current study, the rate of endemic goitre in the state of Colima was 3.42 per 100000 inhabitants and, according to the Ministry of Health, Colima was classified as having a low level of salt iodination ${ }^{(23)}$. The presence of goitre in the region is known on the basis of hospital reports of thyroid gland surgery for massive goitre, as well as clinical observations made by physicians attending patients with the condition, and by casual observations made on walking around rural town streets, where it is common to see goitrous adults over the age of 50 years.

The objectives of the present study were to determine whether there was iodine deficiency and its likely causes, and to evaluate its association with IQ in schoolchildren in Cuauhtémoc, Colima, Mexico.

\section{Materials and methods}

\section{Setting}

The study took place in Cuauhtémoc, a municipality located $15 \mathrm{~km}$ to the north-east of the capital city of Colima. Its altitude ranges from 600 to $2700 \mathrm{~m}$ above sea level. The local geography is marked by slopes forming irregular longitudinal creases from north to south and south-east, and centuries of erosion have caused multiple ravines. The soil, classified as mountain or transition soil, is clayey, with varying percentages of sand and mud, and it contains a high percentage of volcanic rock ${ }^{(24)}$. The municipality is close to the nearby coastal area of Cuyutlán, where sea salt is processed and iodated in salt ponds of sea water; often, non-iodated salt that has been designated for industrial use ends up being used for human consumption ${ }^{(23)}$.

\section{Study design and participants}

A cross-over analytical study was carried out from November 2002 to July 2003 in 13 communities in the municipality of Cuauhtémoc, Colima.

Out of the 19 public elementary schools available, children of both sexes, in grades 1 to 6 , from the morning and afternoon shifts, were included in the study. Participating individuals were randomly selected from each school's student list. A sample of 288 individuals was calculated as required to assess the expected association between IQ and iodine nutritional status, setting a 0.05 probability in a two-tailed test $(Z=1.960)$ with 0.05 precision to estimate the odds ratio ${ }^{(25)}$. With an additional margin for possible study rejection or biochemical determination problems, we took a sample of 303 children.

\section{Determinations}

An index composed of 10 relevant variables was used to assess socio-economic level ${ }^{(26)}$. Variables included parents' occupation, amount of money spent on food, number of families living under the same roof, number of people living in the same household, number of rooms used for sleeping, number of selected material possessions, and type of home construction material (walls, roof, floor). Each variable was given a numerical value in which the higher number was assigned to the more favourable condition. The total score was divided into tertiles, corresponding to upper, middle and lower socioeconomic level, as proposed elsewhere ${ }^{(27)}$.

Children's weights were taken using an electronic scale with a precision of $100 \mathrm{~g}$. Standing height was measured using a measuring scale with $1 \mathrm{~mm}$ precision. Before data collection, field personnel were trained in standardised 
anthropometric techniques and procedures ${ }^{(28)}$. Body mass index (BMI) $\left(\mathrm{kg} / \mathrm{m}^{2}\right)$ was calculated and percentile values were used to classify nutritional status as underweight $(\leq \mathrm{P} 5)$, normal weight $(>\mathrm{P} 5$ to $<$ P85), overweight $\left(\geq \mathrm{P} 85\right.$ to $<$ P95) and obese $(\geq \mathrm{P} 95)^{(29)}$.

Raven's progressive matrices test, including the coloured scale with $\mathrm{A}, \mathrm{AB}$ and $\mathrm{B}$ sets, was used to determine IQ, applied by a trained psychologist. This instrument has an internal consistency coefficient of 0.8975 and a Guttmann $\alpha$ value of 0.7235 to 0.9160 in the Mexican population ${ }^{(30)}$. Scores were transformed into percentile values and IQ was categorised as low $(\leq \mathrm{P} 5)$, below average $(>\mathrm{P} 5$ to $\leq \mathrm{P} 25)$, average $(>\mathrm{P} 25$ to $<\mathrm{P} 75)$, above average $(\geq \mathrm{P} 75$ to $<\mathrm{P} 95)$ and high $(\geq \mathrm{P} 95)$. This scale has been previously validated in a population similar to the one under study ${ }^{(31)}$. Given that the study design did not allow for the control of whether the participants had eaten breakfast or some kind of food before the test application, this potential confounder was controlled for in the analysis.

An endocrinologist previously trained and standardised in the clinical assessment of thyroid size classified it as: Grade 0, normal gland, not palpable or visible; Grade 1, gland palpable when the neck is extended, but not visible; Grade 2, gland palpable and visible ${ }^{(32)}$. Intraobserver variability assessed before initiating fieldwork showed $\alpha=0 \cdot 67$.

Urine samples were collected in the schools. With the assistance of a parent and a study nurse, each child provided a urine sample of approximately $50 \mathrm{ml}$ in a plastic cup. A $10 \mathrm{ml}$ aliquot of urine was stored at $-70^{\circ} \mathrm{C}$ in Sarstedt Monometer tubes until processing. The manual acid digestion method of Sandell-Kolthoff was used to determine urinary iodine ${ }^{(33)}$. The following cut-offs and definitions were used ${ }^{(4)}:<20 \mu \mathrm{g} / 1$, severe deficiency; 20-49 $\mu \mathrm{g} / 1$, moderate deficiency; 50-99 $\mathrm{g} / \mathrm{l}$, slight deficiency; 100-199 $\mu \mathrm{g} / 1$, adequate iodine status; 200-299 $\mu \mathrm{g} / 1$, risk of iodine-induced hyperthyroidism; $>300 \mu \mathrm{g} / \mathrm{l}$, excessive iodine status, associated with risk of adverse health consequences.

A $5 \mathrm{ml}$ venous blood sample was taken from participants, first thing in the morning, into tubes containing ethylenediaminetetraacetic acid (Vaccutainer; Becton Dickinson), centrifuged for $8 \mathrm{~min}$ at $3000 \mathrm{rev} / \mathrm{min}$ to separate the serum, and stored at $-70^{\circ} \mathrm{C}$ until processing. Haemoglobin, haematocrit and mean corpuscular volume determinations were carried out in a T-540 Coulter cell counter, using the cyanomethaemoglobin method, with regular control values run during the study. Serum iron and total iron-binding capacity (TIBC) were determined using a flame atomic absorption spectrophotometry method $^{(34)}$, with a model 300 spectrophotometer equipped with a graphite furnace (HGH-2000) and a deuterium background corrector (all from Perkin-Elmer). Serum ferritin was determined by the two-stage immunoradiometric method (Diasorin). Erythrocyte protoporphyrin was determined by the photofluorometric method in a model 2010 hematofluorometer (AVIV Biomedical Inc., Lakewood, NJ, USA) using controls daily and at every 50 determinations.

The frequency of consumption of the following goitrogens: peanuts (Arachis bypogaea L.), cabbage (Brassica oleracea), sweet potato (Ipomoea batatas), broccoli (Brassica oleracea italica), cauliflower (Brassica oleracea) and manioc (Manibot esculenta Crantz), were obtained by a nutritionist through direct interview with the participants' parents ${ }^{(35)}$.

Two hundred and eighty-one samples of salt used for everyday consumption were collected from the study subjects' homes. Potassium iodate content was estimated by means of a semi-quantitative method that resorts to a colour scale, with colour graduations equivalent to 0,25 , 50,75 and $100 \mathrm{ppm}$, with \pm 10 ppm precision ${ }^{(32)}$.

Casual samples from community water sources were collected. As the metabolism of Escherichia coli and similar organisms produces organosulphur compounds that, when ingested in drinking water, interfere with the synthesis of thyroid hormones, thus contributing as an environmental goitrogen $^{(36)}$, coliform bacteria (total coliforms, thermotolerant bacteria and E. coli) were measured in $100 \mathrm{ml}$ of water, by filtration. The Mexican official norm approves water for human consumption and use with up to $2 \mathrm{CFU}$ (colony-forming units) $/ 100 \mathrm{ml}$ for total coliform bacilli, and $0 \mathrm{CFU} / 100 \mathrm{ml}$ for faecal coliforms ${ }^{(37)}$.

The project was approved by the institutional Local Research and Ethics Committee and by the authorities of the Department of Education in Cuauhtémoc. The directors of each of the participating schools agreed to carry out the study. Parents and children who agreed to participate signed a letter of informed consent. All children with data suggesting iodine deficiency or clinical goitre were referred to a health service for evaluation and treatment.

\section{Statistical analyses}

Descriptive analyses included the median and range for variables that were not normally distributed. A random pattern for missing data was identified by connecting this information to the participant's place of origin. In the case of missing values for height we resorted to the hot-deck imputation procedure (Stata), taking data from study subjects from the same school, school year, gender and weight, and BMI was calculated from these measurements. We felt confident to take these data for imputation based on the fact that missing values came from children from the same geographical community, same school, similar age, similar socio-economic environment, and with no apparent bias in missing data, so there was a high likelihood that the missing height measurements had the same distribution as those that were registered; also, height distribution would be independent of IQ distribution (data not shown). Bivariate analyses were 
carried out using the $\chi^{2}$ or the Fisher exact test statistic for categorical variables, and one-way analysis of variance (ANOVA) for quantitative variables, setting statistical significance at $P<0 \cdot 05$. Multivariate analyses were run using logistic regression models to identify the strongest predictors for IQ. Variables that were likely predictors of children's IQ were selected based on the theoretical framework, and were manually included in the models to explore their predictive capacity, judging the goodnessof-fit by the probability coefficient. Effect modification was evaluated through the inclusion of interaction variables. The two models with the greatest prediction capacity are presented, along with the corresponding odds ratio (OR) as the measure of association ${ }^{(38)}$.

\section{Results}

The sample consisted of 303 children between 6.03 and 14.6 years of age (mean 9.35 years, standard deviation 1.88 years), nearly evenly distributed by sex. Physical examination of the thyroid gland showed a prevalence of Grade 1 goitre (palpable but not visible) of $19.1 \%$ and a $2 \cdot 3 \%$ prevalence of Grade 2 goitre (palpable and visible). Nearly $30 \%$ of the children had normal urinary iodine values; $19.5 \%$ had low urinary iodine and $32.0 \%$ had excessive urinary iodine. According to the IQ score distribution, $4.9 \%$ of the population was in the high category, $3.6 \%$ in the above-average, $18.8 \%$ in the average, $24.2 \%$ in the below-average and $48.5 \%$ in the low category. There were no significant statistical differences when comparing IQ scores between boys and girls, nor when comparing the mean age in the IQ category percentiles (Table 1). There were no statistically significant differences among urinary iodine values analysed by IQ category (ANOVA $P=0 \cdot 129$ ). There were also no statistically significant differences between urinary iodine values and IQ classification category frequencies (Table 2). A low IQ score, as determined by the progressive matrices test, was demonstrated in $51.8 \%$ of the children with normal-sized thyroid gland, with a marginally statistically significant value $(P=0.052)$ (Table 3$)$.

Large-grain sea salt was the type most commonly used $(92 \%, 258 / 281)$ by families for daily consumption. Only $3 \%$ of the population studied used table salt, most using the brands 'La Fina' (62.5\%) or 'Cisne' (12.5\%). Both of these are bottled by Sales del Istmo, Mexico's principal salt bottling plant, where previous studies have demonstrated adequate iodination of these salts ${ }^{(39)}$. Six per cent of the population used both sea salt and table salt. Potassium iodate saturation analysis was carried out on 114 of the collected samples. Adequate iodine saturation levels were found in $13.16 \%$ of samples and $18.84 \%$ had low levels $(<50 \mathrm{ppm}) ; 90 \%$ of the sea salt analysed had low iodine saturation $(<50 \mathrm{ppm})$ and $75 \%$ of the table salt had adequate iodine saturation. Overall, $66 \%$ of
Table 1 Descriptive characteristics, goitre prevalence and urinary iodine values in 303 children aged 6 to 14 years in a random sample from 19 participating schools in different communities of the municipality of Cuauhtémoc, Colima

\begin{tabular}{|c|c|c|}
\hline Characteristic & $n$ & $\%$ \\
\hline Age (years), median (range) & \multicolumn{2}{|c|}{$9.48(6.0,14.6)$} \\
\hline \multicolumn{3}{|l|}{ Sex } \\
\hline Boys & 153 & 50.5 \\
\hline Girls & 150 & 49.5 \\
\hline BMI $\left(\mathrm{kg} / \mathrm{m}^{2}\right)$, median (range) & \multicolumn{2}{|c|}{$17.70(11.20,47 \cdot 20)$} \\
\hline \multicolumn{3}{|l|}{ Nutritional status in relation to $\mathrm{BMI}$} \\
\hline Underweight & 6 & $2 \cdot 0$ \\
\hline Normal & 170 & $56 \cdot 1$ \\
\hline Overweight & 55 & $18 \cdot 1$ \\
\hline Obese & 72 & 23.8 \\
\hline \multicolumn{3}{|l|}{ Elementary school grade attended } \\
\hline 1st grade & 41 & 13.5 \\
\hline 2nd grade & 52 & $17 \cdot 2$ \\
\hline 3rd grade & 57 & 18.8 \\
\hline 4th grade & 60 & $19 \cdot 8$ \\
\hline 5 th grade & 51 & $16 \cdot 8$ \\
\hline 6th grade & 42 & 13.9 \\
\hline \multicolumn{3}{|l|}{ Socio-economic level } \\
\hline Lower (1st tertile) & 100 & 33.0 \\
\hline Middle (2nd tertile) & 129 & $42 \cdot 6$ \\
\hline Upper (3rd tertile) & 74 & 24.4 \\
\hline \multicolumn{3}{|l|}{ Goitre* $^{*}$} \\
\hline Grade 0 & 238 & $78 \cdot 6$ \\
\hline Grade 1 & 58 & $19 \cdot 1$ \\
\hline Grade 2 & 7 & $2 \cdot 3$ \\
\hline Urinary iodine $(\mu \mathrm{g} / \mathrm{l})$, median (range) & \multicolumn{2}{|c|}{$201(7,500)$} \\
\hline \multicolumn{3}{|l|}{ Urinary iodine statust } \\
\hline Severe deficiency & 5 & $1 \cdot 7$ \\
\hline Moderate deficiency & 21 & 6.9 \\
\hline Slight deficiency & 33 & $10 \cdot 9$ \\
\hline Normal urinary iodine & 90 & 29.7 \\
\hline Hyperthyroidism risk & 57 & $18 \cdot 8$ \\
\hline Excessive & 97 & $32 \cdot 0$ \\
\hline \multicolumn{3}{|l|}{ IQ‡ } \\
\hline Low & 147 & 48.5 \\
\hline Below average & 73 & 24.2 \\
\hline Average & 57 & $18 \cdot 8$ \\
\hline Above average & 11 & 3.6 \\
\hline High & 15 & 4.9 \\
\hline
\end{tabular}

BMI, body mass index; $\mathrm{IQ}$, intelligence quotient.

${ }^{*}$ Graded according to physical examination ${ }^{(32)}$ : Grade 0, normal; Grade 1, palpable and not visible; Grade 2, palpable and visible.

tCategories according to urinary iodine concentration ${ }^{(4)}$ : severe deficiency, $<20 \mu \mathrm{g} / \mathrm{l}$; moderate deficiency, 20-49 $\mu \mathrm{g} / \mathrm{l}$; slight deficiency, 50-99 $\mathrm{g} / \mathrm{/}$; normal, 100-199 $\mathrm{g} / \mathrm{l}$; hyperthyroidism risk, 200-299 $\mathrm{g} / \mathrm{l}$; excessive, $\geq 300 \mu \mathrm{g} / \mathrm{l}$.

$\ddagger$ Categories according to percentile score: low, $\leq \mathrm{P} 5$; below average, $>\mathrm{P} 5$ to $\leq$ P25; average, $>$ P25 to $<$ P75; above average, $\geq$ P75 to $<$ P95; high, $\geq$ P95.

sea and table salts samples had low iodine saturation $(<50$ ppm).

Peanut consumption at least once a week was the most commonly consumed goitrogen $(31.5 \%$ of the population), followed by cabbage (30.1\%), broccoli (27.7\%) and cauliflower (25.7\%). These same foods were consumed only occasionally by $41.8 \%, 29.5 \%, 19.9 \%$ and $21.9 \%$ of the population, respectively. Sweet potatoes were also consumed occasionally by $43.8 \%$ of those interviewed. Manioc was not part of the diet in the majority of the population $(75.3 \%)$, and broccoli and cauliflower were never eaten by $46 \cdot 2 \%$ and $43.8 \%$ of the population, respectively (Table 4 ). 
Table 2 lodine urinary values and status* in relation to IQ+ of 6- to 14-year-old schoolchildren in a random sample from 19 participating schools in different communities in the municipality of Cuauhtémoc, Colima

\begin{tabular}{|c|c|c|c|c|c|c|c|c|c|c|}
\hline \multirow[b]{3}{*}{ Variable } & \multicolumn{10}{|c|}{$\mathrm{IQ}$} \\
\hline & \multicolumn{2}{|c|}{ Low } & \multicolumn{2}{|c|}{ Below average } & \multicolumn{2}{|c|}{ Average } & \multicolumn{2}{|c|}{ Above average } & \multicolumn{2}{|c|}{ High } \\
\hline & $n$ & $\%$ & $n$ & $\%$ & $n$ & $\%$ & $n$ & $\%$ & $n$ & $\%$ \\
\hline Urinary iodine $(\mu \mathrm{g} / \mathrm{l})$, mean $(\mathrm{SD}) \ddagger$ & \multicolumn{2}{|c|}{$213.3(152.4)$} & \multicolumn{2}{|c|}{$268.4(153.6)$} & \multicolumn{2}{|c|}{$248.6(142.9)$} & \multicolumn{2}{|c|}{$234.72(162.9)$} & \multicolumn{2}{|c|}{$234.01(113.8)$} \\
\hline Urinary iodine status $\S$ & & & & & & & & & & \\
\hline Severe deficiency & 4 & $80 \cdot 0$ & 0 & 0 & 0 & 0 & 1 & $20 \cdot 0$ & 0 & 0 \\
\hline Moderate deficiency & 15 & 71.4 & 4 & $19 \cdot 1$ & 2 & 9.5 & 0 & 0 & 0 & 0 \\
\hline Slight deficiency & 21 & 63.6 & 5 & $15 \cdot 0$ & 4 & $12 \cdot 1$ & 1 & 3.0 & 2 & $6 \cdot 0$ \\
\hline Normal & 40 & 44.4 & 21 & 23.3 & 21 & $23 \cdot 3$ & 3 & $3 \cdot 3$ & 5 & $5 \cdot 6$ \\
\hline Hyperthyroidism risk & 28 & 49.1 & 12 & $21 \cdot 1$ & 10 & 17.5 & 3 & $5 \cdot 3$ & 4 & $7 \cdot 0$ \\
\hline Excessive & 39 & $40 \cdot 2$ & 31 & 32.0 & 20 & $20 \cdot 6$ & 3 & 3.0 & 4 & $4 \cdot 1$ \\
\hline
\end{tabular}

$\mathrm{IQ}$, intelligence quotient; SD, standard deviation.

${ }^{*}$ Categories according to urinary iodine concentration ${ }^{(4)}$ : severe deficiency, $<20 \mu \mathrm{g} /$; moderate deficiency, $20-49 \mu \mathrm{g} /$; slight deficiency, 50-99 $\mu \mathrm{g} / \mathrm{l}$; normal, 100-199 $\mu \mathrm{g} /$ /; hyperthyroidism risk, 200-299 $\mu \mathrm{g} /$; excessive, $\geq 300 \mu \mathrm{g} / \mathrm{l}$.

tCategories according to percentile score: low, $\leq \mathrm{P} 5$; below average, $>\mathrm{P} 5$ to $\leq \mathrm{P} 25$; average, $>\mathrm{P} 25$ to $<\mathrm{P} 75$; above average, $\geq \mathrm{P} 75$ to $<\mathrm{P} 95$; high, $\geq \mathrm{P} 95$. $\ddagger P=0.129$ (analysis of variance)

$\S P=0.302$ (Fisher's exact test).

Table 3 Goitre* distribution in relation to IQt of 6- to 14-year-old schoolchildren in a random sample from 19 participating schools in different communities of the municipality of Cuauhtémoc, Colima

\begin{tabular}{|c|c|c|c|c|c|c|c|c|c|c|}
\hline \multirow[b]{3}{*}{ Goitreł } & \multicolumn{10}{|c|}{$\mathrm{IQ}$} \\
\hline & \multicolumn{2}{|c|}{ Low } & \multicolumn{2}{|c|}{ Below average } & \multicolumn{2}{|c|}{ Average } & \multicolumn{2}{|c|}{ Above average } & \multicolumn{2}{|c|}{ High } \\
\hline & $n$ & $\%$ & $n$ & $\%$ & $n$ & $\%$ & $n$ & $\%$ & $n$ & $\%$ \\
\hline Grade 0 & 130 & 51.8 & 56 & $22 \cdot 3$ & 45 & 17.9 & 11 & 4.4 & 9 & 3.6 \\
\hline Grade 1 & 23 & 38.3 & 18 & 30.0 & 14 & 23.3 & 1 & 1.7 & 4 & $6 \cdot 7$ \\
\hline Grade 2 & 2 & $28 \cdot 6$ & 2 & 28.6 & 1 & $14 \cdot 3$ & 0 & 0 & 2 & $28 \cdot 6$ \\
\hline
\end{tabular}

*Graded according to physical examination ${ }^{(32)}$ : Grade 0, normal; Grade 1, palpable and not visible; Grade 2, palpable and visible.

tCategories according to percentile score: low, $\leq$ P5; below average, $>$ P5 to $\leq$ P25; average, $>$ P25 to $<$ P75; above average, $\geq$ P75 to $<$ P95; high, $\geq$ P95. $\ddagger P=0.052$ (Fisher's exact test).

Table 4 Consumption frequency of goitrogenic foods in the population interviewed in the municipality of Cuauhtémoc, Colima

\begin{tabular}{|c|c|c|c|c|c|c|c|c|}
\hline \multirow[b]{2}{*}{ Goitrogenic food } & \multicolumn{2}{|c|}{ Once a week } & \multicolumn{2}{|c|}{ Once a month } & \multicolumn{2}{|c|}{ Occasionally } & \multicolumn{2}{|c|}{ Not part of the diet } \\
\hline & $n$ & $\%$ & $n$ & $\%$ & $n$ & $\%$ & $n$ & $\%$ \\
\hline Peanut (Arachis hypogaea L.) & 92 & 31.5 & 58 & $19 \cdot 9$ & 122 & 41.8 & 20 & 6.8 \\
\hline Sweet potato (Ipomoea batatas) & 28 & 9.6 & 22 & 7.5 & 128 & $43 \cdot 8$ & 114 & $39 \cdot 1$ \\
\hline Manioc (Manihot esculenta Crantz) & 7 & 2.4 & 2 & 0.7 & 63 & 21.6 & 220 & $75 \cdot 3$ \\
\hline Cabbage (Brassica oleracea) & 88 & $30 \cdot 1$ & 31 & $10 \cdot 6$ & 86 & 29.5 & 87 & $29 \cdot 8$ \\
\hline Broccoli (Brassica oleracea italica) & 81 & $27 \cdot 7$ & 18 & $6 \cdot 2$ & 58 & $19 \cdot 9$ & 135 & $46 \cdot 2$ \\
\hline Cauliflower (Brassica oleracea) & 75 & $25 \cdot 7$ & 25 & $8 \cdot 6$ & 64 & 21.9 & 128 & 43.8 \\
\hline
\end{tabular}

${ }^{*}$ Fewer times than once a month.

Coliform organisms were identified predominantly in well water (CFU/100 ml: median 207.5 , range 75,595$)$ and in cisterns (median 151, range 150,152), with predominance of thermo-tolerant forms. Water sampled from private homes had a median of 52 total coliform organisms; in elementary schools the median was 25 , and in kindergartens, 12. E. coli was not found in private homes, elementary schools, kindergartens, public water outlets or water purifying plants, but it was found in well water and in cisterns (Table 5).

Effect modification through the inclusion of contextspecific variables was evaluated in multivariate models to explain IQ scores. Given that children with iron deficiency may be at higher risk of goitre and thyroid insufficiency ${ }^{(40-42)}$, the iron status of the study population was also evaluated and these variables were included in the multivariate models. Model 1 was fitted by frequency of goitrogen consumption and TIBC, and resulted in a maximum probability coefficient closer to zero $(-143 \cdot 23)$. The goodness-of-fit test value showed $\chi^{2}$ of $253.61(P=0.37)$. In this model, the possibility of IQ deficiency among schoolchildren was 4.26 times greater when there was moderate iodine deficiency $(P=0.06)$, compared with the other iodine level categories, and 
Table 5 Coliform organisms in drinking water* in the municipality of Cuauhtémoc, Colima

\begin{tabular}{lccc}
\hline & & \multicolumn{1}{c}{ CFU/100 ml, median (minimum, maximum) } \\
\cline { 2 - 4 } Origin & Total coliforms & Thermo-tolerant coliforms & Escherichia coli \\
\hline Private homes $(n=15)$ & $52(0,210)$ & $8(0,70)$ & $0(0,70)$ \\
Elementary schools $(n=12)$ & $25(0,795)$ & $7(0,554)$ & $0(0,86)$ \\
Kindergartens $(n=9)$ & $12(0,760)$ & $0(0,18)$ & $0(0,16)$ \\
Purifying plants $(n=6)$ & $0(0,278)$ & $0(0,62)$ & $0(0,48)$ \\
Well water $(n=3)$ & $207.5(75,595)$ & $59(0,440)$ & $0,206)$ \\
Public outlets $(n=3)$ & $21(0,74)$ & $0(0,72)$ & $0(0,16)$ \\
Cisterns $(n=2)$ & $151(150,152)$ & $67(34,100)$ & $59(34,84)$ \\
\hline
\end{tabular}

${ }^{*}$ Permissible limit (according to the Mexican Official Standard ${ }^{(37)}$ ) of total coliform organisms, thermo-tolerant organisms or E. coli or faecal coliforms: non-existent or undetectable.

Table 6 Results of the two best multiple regression models accounting for the contribution of context-specific study variables to the IQ scores of school-aged children in the municipality of Cuauhtémoc, Colima

\begin{tabular}{llll}
\hline Variable & Adj OR & $95 \% \mathrm{Cl}$ & $P$ value \\
\hline Model 1 & & & \\
lodine deficiency based on UIE & & & \\
$\quad$ Slight & 1.38 & $0.55,3.50$ & 0.487 \\
$\quad$ Moderate & 4.26 & $0.93,19.55$ & 0.062 \\
$\quad$ Severe & 2.17 & $0.22,21.19$ & 0.503 \\
TIBC & 0.997 & $0.99,1.00$ & 0.058 \\
Cabbage consumption & & & \\
$\quad$ Once a week & 3.07 & $1.13,8.32$ & 0.027 \\
Occasionally & 1.21 & $0.47,3.08$ & 0.068 \\
$\quad$ Not part of the diet & 2.18 & $0.83,5.72$ & 0.113 \\
Broccoli consumption & & & \\
$\quad$ Once a week & 0.68 & $0.18,2.50$ & 0.571 \\
Occasionally & 0.49 & $0.13,1.84$ & 0.292 \\
$\quad$ Not part of the diet & 0.94 & $0.26,3.22$ & 0.902 \\
Model 2 & & & \\
lodine deficiency based on UIE & & & \\
$\quad$ Slight & 1.38 & $0.64,3.79$ & 0.328 \\
$\quad$ Moderate & 4.26 & $0.90,18.01$ & 0.067 \\
$\quad$ Severe & 2.17 & $0.17,14.51$ & 0.686 \\
TIBC & 0.997 & $0.99,1.00$ & 0.058 \\
\hline
\end{tabular}

Adj OR, adjusted odds ratio; $\mathrm{Cl}$, confidence interval; UIE, urinary iodine excretion; TIBC, total iron-binding capacity.

when the model was fitted by TIBC and cabbage and broccoli consumption frequency (Table 6). In Model 2, even though the odds ratio estimator for urinary iodine deficiency was not substantially modified (OR 4.26), the $95 \%$ confidence interval (CI) value was reduced discretely (95\% CI: 0.93, 19.55 in Model 1 vs. 0.90, 18.01 in Model 2), and it was more parsimonious (10 variables for Model 1 vs. four variables for Model 2). Additionally, the improvement of the probability coefficient value $(-161.92)$ and the statistical value for the goodness-of-fit evaluation $(P=0.43)$ pointed to this model as the best one for predicting IQ deficiency. Note that the ingestion of goitrogenic foods was not included and only biochemical determinations such as urinary iodine and TIBC retained predictive value (Table 6). According to this model, the risk of finding IQ deficiency was 4.26 times greater in the presence of moderate iodine deficiency $(P=0.06)$.

\section{Discussion}

The $21.4 \%$ prevalence of goitre in school-aged children was striking, given that universal salt iodination has been a government-regulated practice in Mexico for over 60 years. This programme has been shown to be effective in different evaluations, so at present the Mexican Official Norm establishes $30 \mathrm{ppm}$ of iodine as the standard value to consider adequate iodination of salt for human or animal consumption ${ }^{(43)}$. While this is consistent with current WHO recommendations for adequate salt iodination $^{(4)}$, most countries have fixed the levels of iodine content of salt around $50 \mathrm{ppm}^{(44)}$. According to WHO criteria, a prevalence of goitre $\geq 5 \%$ signals a public health problem ${ }^{(4)}$. In Cuauhtémoc, the prevalence of goitre was well above that cut-off, and was also greater than the prevalences found in two recent studies in Mexico carried out on marginalised indigenous or mestizo areas. One of these studies was carried out among Tarahumara indigenous children in the northern state of Chihuahua, who showed a prevalence of goitre of $7.0 \%{ }^{(45)}$; the other was conducted among school-aged mestizo and Náhuatl indigenous children from the Huasteca region in the central state of Hidalgo, who showed a goitre prevalence of $10 \cdot 4 \%{ }^{(46)}$. Taking urinary iodine excretion as a measure of iodine status, in the present study we found a low level of urinary iodine excretion in $19.5 \%$ of the children. This proportion is lower than that found in the Tarahumara children (38\%) and similar to that found in the children from Huasteca (22\%). It should be noted, however, that goitrogens were present in the environment and the diets of the children in the Huasteca region only. Therefore, marginally low iodine ingestion does not seem to be enough to precipitate goitre. Consistent with previous studies ${ }^{(5,37,46-49)}$, we propose that, despite high urinary iodine levels found in slightly more than half the children included in this study, the presence of goitrogens can explain the marginal or deficient iodine status found in almost $20 \%$ of the sample. In the present study we also investigated the presence of coliform bacteria in drinking water, as these micro-organisms produce organosulphur compounds 
which interfere with thyroid hormone synthesis ${ }^{(37)}$. Other goitrogens, such as those found in food, may also contribute to iodine deficiency. In our study, we identified the consumption of food-based goitrogens such as cabbage and broccoli. These foods belong to the genus Brassica, and contain thiocyanates, isothiocyanates and thioglucosides, which are natural antithyroid compounds. Physiologically, they act by blocking iodine binding by the thyroid gland, which, in turn, impairs thyroid hormonal biosynthesis ${ }^{(47,50)}$

A seemingly contradictory finding was that, in spite of insufficient iodination in $85 \%$ of the samples of salt used daily by the families studied, $32 \%$ of the children were identified as having excess iodine in urine. This finding may just be an artefact of the known imprecision of the semi-quantitative, colorimetric method used to estimate iodine concentration in salt ${ }^{(36)}$. We do recognise this caveat, but we understand that, despite this, it has been the most widely used method to assess the adequacy of salt iodination, as recommended by $\mathrm{WHO}^{(4)}$. Therefore, we propose that a further explanation lies in the fact that urinary iodine excretion is an indicator of recent iodine ingestion, and that its concentration varies rapidly, given the high solubility of iodine in water. On the other hand, we should take into consideration that the population in this region, only $50 \mathrm{~km}$ from the Pacific Ocean, has a long tradition of consuming sea salt. Salt iodination in the nearby coastal region is carried out by local producers either manually or with unsophisticated machinery, so homogeneous distribution of iodine cannot be guaranteed. Thus, some portions of packaged salt may contain more iodine than others, with unequal distribution in the population; this unequal distribution will be reflected in uneven ingestion by the population and, therefore, in wide variations in urinary iodine excretion, as found in this study. A reason for concern is the extent to which the situation found in this study may be present in other locations. While a more dedicated effort to document the extent to which insufficiently iodinated salt is distributed and consumed by the population is certainly warranted, we know that throughout the Mexican Pacific coast there are different salt producers, specifically in the coastal states of Baja California, Sinaloa, Sonora, Jalisco, Michoacán, Guerrero and Oaxaca, as well as in Tamaulipas, situated on the Gulf of Mexico ${ }^{(51)}$. While sea salt is often sought, either by locals or by tourists who find a different, presumably better, flavour in it, when this insufficiently or unevenly iodinated salt is consumed on a daily basis, the probability of inadequate iodine consumption, together with the presence of goitrogens in the diet, may replicate our findings.

Our findings take on greater relevance because of the increased risk for low IQ scores in the presence of low urinary iodine values in this population of schoolchildren. While there is not a straightforward correspondence between IQ scores and urinary iodine values, due to the fact that the latter is an indicator of short-term iodine ingestion while the former is affected over time by different variables, still our multiple regression analysis found a four times greater probability of lower IQ scores in association with moderate iodine deficiency, after controlling for biochemical indicators like TIBC and the frequency of consumption of goitrogenic foods. Therefore, although many factors determine IQ, the fact that moderate iodine deficiency was the only variable in the multiple regression models that consistently showed an increased risk of lower IQ scores should be a reason for concern, and the fact that this association was present in a population of school-aged children should not be overlooked.

There were several limitations in our study, such as the lack of determination of other goitrogens in the environment, including heavy metals in the drinking water, specifically mercury, arsenic and lithium. These metals compete for iodine binding, limiting its availability for thyroid synthesis, thus accounting for their goitrogenic effect. In an endemic goitre zone of Central Africa, consumption of goitrogens, associated with the presence of selenium, was identified as a risk factor in mixed oedematous endemic cretinism ${ }^{(49)}$. It would also have been useful to carry out a wider range of bacteriological determinations of drinking water, because we only focused on the identification of global content of coliform organisms.

The most efficacious, feasible and economic way to eradicate iodine deficiency is by fortifying salt for human and animal consumption. However, our results suggest that in regions such as the one studied, the impact of the national iodination programme may have been compromised both by the widespread consumption of salt that has not been adequately fortified as well as by the presence of different goitrogens in the environment. It is an enormous challenge for the government to effectively supervise all salt extractors and producers in the country. However, this must be done if IDD among the population are to be eliminated. The results of the present study should be a wake-up call, both to not lower the standards of adequate salt iodination and to continuously monitor the effectiveness of national iodination programmes. In spite of adequate iodine ingestion by some segments of the population, below-optimum levels of iodine in the environment, combined with the presence of different goitrogens, not only perpetuate the problems of iodine deficiency but also have a negative impact on children's IQ, thus affecting human capital acquisition for the region and the country.

\section{Acknowledgements}

The authors are grateful to Dr Carlos Enrique Tene for goitre evaluation in the field study and to Ms Tania Carranco for her role in organising the fieldwork. The authors acknowledge the participation of the Delattre 
Laboratory at the Louis Pasteur Institute in France for carrying out the microbiological analysis of the water, in accordance with official international standards as well as those of the Mexican official norm. Likewise, the authors acknowledge the participation of the National Institute of Epidemiological Diagnosis and Reference (INDRE) of the Secretary of Health in Mexico for the determinations of urinary iodine. The project received funding from Instituto Mexicano del Seguro Social (grant no. 2002101-0010). The authors declare that there are no conflicts of interest involved in this paper.

\section{References}

1. Hetzel BS (1994) Iodine deficiency and fetal brain damage. N Engl J Med 331, 1770-1771.

2. Delange F (2000) The role of iodine in brain development. Proc Nutr Soc 59, 75-79.

3. Dunn JT \& Delange F (2001) Damaged reproduction: the most important consequence of iodine deficiency. J Clin Endocrinol Metab 86, 2360-2363.

4. International Council for Control of Iodine Deficiency Disorders/United Nations Children's Fund/World Health Organization (2001) Assessment of Iodine Deficiency Disorders and Monitoring their Elimination: A Guide for Programme Managers, 2nd ed. Geneva: WHO.

5. Hetzel B, Potter B \& Dulberg E (1990) The iodine deficiency disorders: nature, pathogenesis and epidemiology. World Rev Nutr Diet 62, 59-119.

6. Bernal J \& Nunez J (1995) Thyroid hormones and brain development. Eur J Endocrinol 133, 390-398.

7. Chan S \& Kilby M (2000) Thyroid hormone and central nervous system development. J Endocrinol 165, 1-8.

8. Delange F (1994) The disorders induced by iodine deficiency. Thyroid 4, 107-128.

9. Boyages S \& Guttikonda K (2000) Iodine status of Australia: look before we leap! Med J Aust 172, 348.

10. Delange F (2001) Iodine deficiency as a cause of brain damage. Postgrad Med 77, 217-220.

11. Pharoah P, Buttfield I \& Hetzel B (1971) Neurological damage to the fetus resulting from severe iodine deficiency during pregnancy. Lancet 1, 308-310.

12. Glinoer D \& Delange F (2000) The potential repercussions of maternal, fetal, and neonatal hypothyroxinemia on the progeny. Thyroid 10, 871-887.

13. Boyages S, Collins J, Maberly G, Jupp JJ, Morris J \& Eastman CJ (1989) Iodine deficiency impairs intellectual and neuromotor development in apparently-normal persons. A study of rural inhabitants of north-central China. Med J Aust 150, 676-682.

14. Tiwari B, Godbole M, Chattopadhyay N, Mandal A \& Mithal A (1996) Learning disabilities and poor motivation to achieve due to prolonged iodine deficiency. Am J Clin Nutr 63, 782-786.

15. Angermayr L \& Clar C (2004) Iodine supplementation for preventing iodine deficiency disorders in children. Cochrane Database Syst Rev (2), CD003819.

16. Zimmermann M, Adou P, Torresani T, Zeder C \& Hurrell R (2000) Iron supplementation in goitrous, iron-deficient children improves their response to oral iodized oil. Eur J Endocrinol 142, 217-223.

17. Zimmermann MB, Connolly K, Bozo M, Bridson J, Rohner F \& Grimci L (2006) Iodine supplementation improves cognition in iodine-deficient schoolchildren in Albania: a randomized, controlled, double-blind study. Am J Clin Nutr 83, 108-114.
18. Sebotsa M, Dannhauser A, Jooste P \& Joubert G (2003) Prevalence of goitre and urinary iodine status of primaryschool children in Lesotho. Bull World Health Organ 81, $28-34$.

19. United Nations Administrative Committee on Coordination/ Sub-Committee on Nutrition (2000) 4th Report on World Nutrition Situation - Nutrition Throughout the Life Cycle. http://www.unsystem.org/scn/archives/rwns04/index.htm (accessed June 2007).

20. Andersson M, Takkouche B, Egli I, Allen HE \& de Benoist B (2005) Current global iodine status and progress over the last decade towards the elimination of iodine deficiency. Bull World Health Organ 83, 518-525.

21. Bellamy C (1999) The State of the World's Children 1999. New York: UNICEF.

22. Hetzel BS (2002) Eliminating iodine deficiency disorders: the role of the International Council in the global partnership. Bull World Health Organ 80, 410-412.

23. Secretaría de Salud (2003) Programa de Acción: Protección contra Riesgos Sanitarios. Sistema Federal de Protección Sanitaria, $1^{\mathrm{a}}$ ed. México, DF: Secretaría de Salud.

24. Secretaría de Gobernación (1999) Enciclopedia de los Municipios de México. Mexico, DF: Instituto Nacional para el Federalismo y el Desarrollo Municipal.

25. Browner WS, Newman TB, Cumming SR \& Hulley S (2001) Estimating sample size and power: the nitty-gritty. In Designing Clinical Research, 2nd ed., pp. 65-91 [SB Hulley, SR Cummings, WR Browner, D Grady, N Hearst and TB Newman, editors]. Philadelphia, PA: Lippincott Williams \& Wilkins.

26. Martínez Salgado H \& Pérez-Gil SE (2000) Selección de indicadores socioeconómicos en los estudios comunitarios sobre salud y nutrición. Nutr Clin 3, 66-77.

27. Shi Z, Lien N, Kumar B, Dalen I \& Holmboe-Ottesen G (2005) The sociodemographic correlates of nutritional status of school adolescents in Jiangsu Province, China. $J$ Adolesc Health 37, 313-322.

28. Gordon CC, Chumlea WC \& Roche A (1988) Measurement descriptions and techniques: stature, recumbent length, and weight. In Anthropometric Standardization Reference Manual, pp. 3-8 [T Lohman, A Roche and R Martorell, editors]. Champaign, IL: Human Kinetics Publishers.

29. Must A, Dallal G \& Dietz W (1991) Reference data for obesity: 85th and 95th percentiles of body mass index $\left(\mathrm{wt} / \mathrm{ht}^{2}\right)$ and triceps skinfold thickness. Am J Clin Nutr $\mathbf{5 3}$, 839-846.

30. Raven J (1999) TEST Matrices Progresivas, Escalas Coloreada, General y Avanzada. México, DF: Editorial Paidós Mexicana SA.

31. Abdel-Khalek A (2005) Reliability and factorial validity of the standard progressive matrices among Kuwaiti children ages 8 to 15 years. Percept Mot Skills 101, 409-412.

32. World Health Organization/United Nations Children's Fund/International Council for Control of Iodine Deficiency Disorders (1994) Indicators for Assessing Iodine Deficiency Disorders and Their Control through Salt Iodization. Geneva: WHO.

33. Dunn J, Crutchfield H, Gutekunst R \& Dunn AD (1993) Two simple methods for measuring iodine in urine. Thyroid 3, 119-123.

34. Olson AD \& Hamlin WB (1960) A new method for serum iron and total iron-binding capacity by atomic absorption spectrophotometry. Clin Chem 15, 438-444.

35. Martinez M (1979) Catálogo de Nombres Vulgares y Científicos de Plantas Mexicanas, $1^{\mathrm{a}}$ ed. México, DF: Fondo de Cultura Económica.

36. Gaitan E (1990) Goitrogens in food and water. Annu Rev Nutr 10, 21-39.

37. Secretaría de Salud (2000) Modificación a la Norma Oficial Mexicana NOM-127-SSA1-1994, Salud ambiental. Agua 
para uso y consumo humano. Límites permisibles de calidad y tratamientos a que debe someterse el agua para su potabilización. Diario Oficial de la Federación 20 de junio.

38. Kleinbaum DG, Kupper LL, Muller KE \& Nizam A (1998) Logistic regression analysis. In Applied Regression Analysis and Other Multivariable Methods, 3rd ed., pp. 656-686 [A Kugushev, editor]. Pacific Grove, CA: Duxbury Press.

39. Martínez Salgado H, Tovar Zamora E, Chávez Villasana A, Armendáriz DM \& Baz-Díaz-Lombardo G (1993) Consumo familiar e individual de sal de mesa en el Estado de México. Salud Publica Mex 35, 630-636.

40. Azizi F, Mirmiran P, Sheikholeslam R, Hedayati M \& Rastmanesh R (2002) The relation between serum ferritin and goiter, urinary iodine and thyroid hormone concentration. Int J Vitam Nutr Res 72, 296-299.

41. Siavash Dastjerdi M, Hashemipour M, Rezvanian H, Kazemi F, Najafian A, Mohammady M, Aminorroaya A, Amini M, Kachuei A \& Hassan Moaddab M (2006) Iron deficiency in goitrous schoolchildren of Semirom, Iran. Horm Res $\mathbf{6 6}$, $45-50$.

42. Hess S, Zimmermann M, Arnold M, Langhans W \& Hurrell RF (2002) Iron deficiency anemia reduces thyroid peroxidase activity in rats. J Nutr 132, 1951-1955.

43. Secretaría de Salud (2003) Norma Oficial Mexicana NOM038-SSA2-2002. Para la prevención, tratamiento y control de las enfermedades por deficiencia de yodo. Diario Oficial de la Federación 13 de septiembre.
44. Mannar V, The Micronutrient Initiative Ottawa Canada \& Dunn JT (1995) Salt Iodization for the Elimination of Iodine Deficiency. Charlottesville, VA: University of Virginia Health Sciences Center.

45. Monarrez-Espino J \& Greiner T (2005) Iodine nutrition among indigenous Tarahumara schoolchildren in Mexico. Eur J Clin Nutr 59, 1213-1216.

46. Martinez Salgado H, Castañeda Limones R, Lechuga Martín del Campo D, Ramos-Hernández RI, Orozco-López M, Rivera-Dommarco J, Mendoza I \& Magos C (2002) Deficiencia de yodo y otros posibles bociógenos en la persistencia del bocio endémico en México. Gac Med Mex 138, 149-156.

47. Chandra A, Mukhopadhyay S, Lahari D \& Tripathy S (2004) Goitrogenic content of Indian cyanogenic plant foods and their in vitro anti-thyroidal activity. Indian J Med Res 119, 180-185.

48. Elnour A, Hambraeus L, Eltom M, Dramaix M \& Bourdoux P (2000) Endemic goiter with iodine sufficiency: a possible role for the consumption of pearl millet in the etiology of endemic goiter. Am J Clin Nutr 71, 59-66.

49. Vanderpas J (2006) Nutritional epidemiology and thyroid hormone metabolism. Annu Rev Nutr 26, 293-322.

50. Stoewsand G (1995) Bioactive organosulfur phytochemicals in Brassica oleracea vegetables - a review. Food Chem Toxicol 33, 537-543.

51. Secretaría de Economía (2007) Sal. Minería 2007. http:// www.economia.gov.mx/?P=1061 (accessed July 2007). 